HANNA MAKURAT

Uniwersytet Gdański

\title{
FRAZEOLOGIZMY W PRZEKŁADZIE NA JEZZYK KASZUBSKI BAŚNI JANA DRZEŻDŻONA
}

Celem niniejszego artykułu jest zaprezentowanie związków frazeologicznych, które pojawiły się w przekładanych na język kaszubski baśniach autorstwa Jana Drzeżdżona, przeanalizowanie ich pod kątem zachowania odpowiedniości tłumaczeniowej oraz ocena strategii translatorskiej przyjętej przez tłumacza. Frazeologizm jest w niniejszej pracy rozumiany jako „dwu- lub kilkuwyrazowa konstrukcja językowa, której znaczenia nie da się wyprowadzić ze znaczeń i reguł łączenia składających się na nią wyrazów" (Polański 2003: 244), a której zastosowanie w tekście ma służyć budowaniu obrazowania i ekspresji (Kochański, Klebanowska, Markowski 1989: 298).

Zadaniem tłumacza literatury pięknej jest znalezienie ekwiwalentów jednostek językowych pojawiających się różnych poziomach budowy tekstu literackiego. Związki frazeologiczne są tymi elementami mowy, których przełożenie na język obcy wymaga od autora translacji szczególnej uwagi. Te dwu- lub kilkuwyrazowe stałe połączenia wyrazowe są semantycznie i syntaktycznie niepodzielne, dlatego ich sensu nie można wyprowadzić ze znaczeń i zasad powiązania składających się na nie elementów (Polański 2003: 244). Stanowią one struktury, których funkcjonowanie w języku jest usankcjonowane konwencją oraz tradycją językową, a ich przekład na język obcy wymaga odkodowania całych konstrukcji wraz z ugruntowanymi w nich informacjami kulturowymi, obrazowością, ekspresywnością i właściwą tego typu połączeniom wyrazowym stylistyką. Jednostki te w procesie translacji muszą być zatem traktowane kompleksowo i często mają w języku docelowym inną formę niż w języku wyjściowym (Dąmbska-Prokop 2000: 107-108).

Znalezienie ekwiwalentu związku frazeologicznego w języku przekładu nie zawsze jest możliwe, choć trzeba zwrócić uwagę, że poszukiwanie w języku docelowym odpowiedników, również będących frazeologizmami, to najbardziej adekwatny sposób translacji tego typu elementów języka - pozwalający na zachowanie symetrii między pierwowzorem a przekładem. Niekiedy jednak możemy mieć do czynienia z ekwiwalencją częściową lub konstrukcjami analogicznymi bądź też z zupełnym brakiem ekwiwalentów w języku docelowym (Мокиенко 2014: 18-19). W przypadku, gdy nie da się odnaleźć w języku przekładu żadnych odpowiedników związku frazeologicznego, można posłużyć się parafrazą, jed- 
nakże opisowa wykładnia zasadniczo jest akceptowana jedynie w sytuacji, gdy faktycznie żadne ekwiwalenty struktur frazeologicznych nie istnieją w języku docelowym (Koller 2007: 606). Możliwe jest też wykorzystanie odpowiedników funkcjonalnych, czyli takich konstrukcji obecnych w kulturze docelowej, które stanowią ekwiwalenty nieznanych czytelnikowi przekładu struktur zarejestrowanych w pierwowzorze. Niektórzy autorzy translacji w sytuacji braku właściwego odpowiednika posługują się hiperonimem, czyli wyrazem lub konstrukcją językową o znaczeniu bardziej ogólnym niż to użyte w tekście wyjściowym. Kolejną techniką translatorską jest tłumaczenie syntagmatyczne, tj. dosłowne bez żadnych objaśnień bądź też z objaśnieniami w formie przypisów lub komentarzy. Najmniej akceptowalnym sposobem dokonywania translacji jest elipsa, czyli pominięcie trudnych do przełożenia kontekstów kulturowych (Hejwowski 2007: 76-83).

Materiałem badawczym niniejszej pracy są jednostki frazeologiczne, pojawiające się w baśniach Jana Drzeżdżona wydanych w postaci bilingwalnego zbioru pt. Baśnie. Brawãdë, opublikowanego przez Zrzeszenie Kaszubsko-Pomorskie w 2012 roku (Drzeżdżon 2012). Translacji na język kaszubski dokonał pisarz i tłumacz kaszubski Roman Drzeżdżon.

Nie dziwi fakt, że proza Jana Drzeżdżona współcześnie została przetłumaczona na kaszubszczyznę. Był to autor, którego twórczość była silnie zakorzeniona w świadomości kaszubskiej i który kultywował macierzystą mowę jako nośnik kultury regionalnej, walcząc o jej przetrwanie (Kossak-Główczewski 2007: 84). Był on pisarzem bilingwalnym, wiele utworów napisał w języku kaszubskim, jednak również te jego dzieła, które tworzył po polsku, sięgają do kaszubskich korzeni i prezentują domową kulturę kaszubską. Analizowane tutaj, pisane po polsku, baśnie Jana Drzeżdżona zajmują ważne miejsce w literaturze regionalnej Kaszub - z jednej strony są one elementem lokalnej kaszubskiej folklorystycznej twórczości ludowej, a drugiej strony - autor podejmuje w nich tematy uniwersalne i odwieczne. Daniel Kalinowski słusznie zwrócił uwagę, że w prozę omawianego tu autora wpisany jest dialog z tradycją rodzimą oraz tą wychodzącą poza krąg kaszubski (Kalinowski 2007: 54-55).

Omawiając translację baśni Jana Drzeżdżona na kaszubszczyznę, trzeba zaakcentować, że przekłady literatury pięknej z języka polskiego na język kaszubski mają inne cele niż tylko przekazanie treści w języku docelowym. Kaszubskojęzyczni czytelnicy zasadniczo są dwujęzyczni i znają także język polski, w związku z czym nie ma konieczności tłumaczenia tekstu na język regionalny w celu pozyskania nowych odbiorców. Translacje na kaszubszczyznę mają raczej za zadanie podniesienie jej statusu i usytuowania wśród innych języków (Makurat 2017a: 283, Makurat 2017c: 95). Jednocześnie trzeba zwrócić uwagę, że przekłady z języka bardziej rozwiniętego na język mniej rozwinięty mogą implikować potrzebę użycia w języku docelowym nowych elementów językowych, przyczyniając się do jego rozwoju. Język o dłuższej tradycji, z którego przekłada się teksty na język mniej ukształtowany, może modelować ten drugi poprzez dostarczanie mu modeli i konwencji językowych (Krysztofiak 1996: 135). Jerzy Treder słusznie zauważył, że tłumaczenia tekstów z języka polskiego na kaszubski mogą pomagać w udoskonalaniu zarówno samej kaszubszczyzny, jak i warsztatu twórczego kaszubskich autorów (Treder 2006: 262). Jednocześnie warto przywołać pogląd Wojtasiewicza, który stwierdził w sytuacji przekładu z języka bogatszego w środki językowe na język uboższy może pojawić się problem z utrzymaniem precyzji językowej (Wojtasiewicz 1992: 28-64). Trudność ta często obser- 
wowane jest w przypadku translacji z języków obcych na kaszubszczyznę. Trzeba jednak przyznać, że mimo pewnych kłopotliwych kwestii związanych z przedstawieniem ekwiwalentnych znaczeń ostatecznie język kaszubski jest na tyle bogaty i operatywny, że można w nim wyrazić treści artystyczne (Kalinowski 2012: 29). Podczas tłumaczenia na kaszubszczyznę związków frazeologicznych również nie zawsze udaje się utrzymać całkowitą odpowiedniość, choć większość przekładów jest zasadniczo udana.

Struktury frazeologiczne odnotowane w przekładzie książki Baśnie. Brawãdë Jana Drzeżdżona można podzielić na kilka grup. Pierwsza z nich obejmuje związki frazeologiczne przełożone syntagmatycznie (wyodrębniono tu następujące konstrukcje: zgrzytać zębami, włos się jeży, być w czyichś rękach). Druga grupa to frazeologizmy, dla których autor przekładu starał się zbudować opisową wykładnię (brać się z kimś za bary, pozostawić komuś wolna rękę, zalewała go fala wielkiego przygnębienia, pędzić na złamanie kar$k u$, mówić od rzeczy). Można też wydzielić trzecią grupę, w której znajdą się kaszubskie związki frazeologiczne, które w tekście wyjściowym nie miały odpowiedników będących frazeologizmami; użycie tych konstrukcji frazeologicznych w tekście docelowym można uznać za przejaw strategii kompensacji (tłumacz czterokrotnie użył kaszubskiego zwrotu bëc òd se w następujących znaczeniach: 'być nieprzytomnym', 'być zmieszanym', 'być oszołomionym, 'być odurzonym') lub za przejaw eufemizacji (autor przekładu zastosował frazeologizm nëkac z bùksama jako odpowiednik polskiego czasownika sikać).

Pierwsza próba thumaczenia związku frazeologicznego na język kaszubski, którą chcę omówić, jest warta szczególnej uwagi, ponieważ podobne konstrukcje zastosowało dwóch kaszubskich autorów. Mianowicie dosłowny przekład frazeologizmu zgrzytać zębami został odnotowany nie tylko w przekładzie baśni Jana Drzeżdżona wykonanym przez Romana Drzeżdżona, ale tej samej kalki językowej z polszczyzny użyła też Bożena Ugowska, thumacząc na kaszubszczyznę książkę Balbina z IV B autorstwa Danuty Stanulewicz (Stanulewicz 2015, Makurat 2017a: 279). Zwrot zgrzytać zębami w języku polskim obok podstawowego znaczenia wskazującego na tarcie zębami żuchwy o zęby szczęki ma też przenośne znaczenie i funkcjonuje jako frazeologizm oznaczający 'złościć się, okazywać gniew, wściekłość' (Dubisz, Sobol 2005: 688). W języku kaszubskim połączenia wyrazowego szrëwòtac zãbama można użyć tylko w odniesieniu do tarcia górnych zębów o dolne, natomiast nie można go stosować w znaczeniu metaforycznym. W polskojęzycznym pierwowzorze baśni Jana Drzeżdżona Anioł $i$ diabet powyższy zwrot został użyty w sensie przenośnym i pojawił się w następującym zdaniu „Diabeł zaś jednym okiem zerkał na anioła i zgrzytał zębami, że sam jest taki gwałtowny, a anioł ma w sobie niemal nieziemską delikatność". Mowa jest tutaj o tym, iż diabeł złościł się o to, że nie jest tak delikatny jak anioł. W kaszubskim wersji tej samej baśni pt. Aniót $i$ diôbet zwrot ten został przełożony dosłownie, w wyniku czego mamy do czynienia z przekładem nieadekwatnym. Być może autor thumaczenia chciał nadać wymienionemu połączeniu wyrazowemu szrëwòtac zãbama znaczenie przenośne, analogiczne do tego znanego polszczyźnie. Przekład powyżej zacytowanego fragmentu wygląda następująco: „Zôs diôbeł jednym òkã pòdzérôł na anioła ë szrëwòtôł zãbama, że sóm je taczi gwôłtowny, a aniół mô w se prawie niezemską delikatnotã". Stworzenie takiej samej kalki językowej z polszczyzny przez Romana Drzeżdżona w książce Baśnie. Brawãdë oraz przez Bożenę Ugowską przekładającą Balbinę z IV B może wynikać stąd, że oboje thumacze sięgali do internetowego Stownika polsko-kaszubskiego Eugeniusza Gołąbka (Gołąbek, II: 1562), w którym zwrot ten został odnotowany, 
jednakże tylko w podstawowym, nieprzenośnym znaczeniu. Roman Drzeżdżon zamiast wprowadzać kalkę językową polskiego frazeologizmu mógł użyć znanych w kaszubszczyźnie struktur frazeologicznych takich, jak: bëc pieprzã òbsëpóny (Sychta 1965-1976, IV: 254), albo miec czôrno w pëskù (Trepczyk 1994, II: 428), które mają także znaczenie 'złościć się, okazywać gniew'.

Autor translacji posłużył się też syntagmatycznym thumaczeniem frazeologizmu w przekładzie baśni Jana Drzeżdżona pt. O człowieku, który bał się śmierci. W pierwowzorze utworu pojawił się związek frazeologiczny włos się jeży, znany też jako włos się komuś jeży na glowie lub włosy się komuś jeża na glowie, oznaczający, że 'kogoś obejmuje wielki strach, przerażenie' (Dubisz, Sobol 2005: 623) bądź też 'coś budzi czyjeś zdumienie, mocno kogoś zaskakuje' (Bąba, Liberek 2003: 921). W polskim oryginale powyższa struktura frazeologiczna pojawiła się w następującym kontekście: „na samą myśl o śmierci włos mu się jeżył". W kaszubskiej translacji powyższy fragment został przetłumaczony następująco: „,zej blós pòmëslôł ò smiercë, włosë stôwałë mù sztram” ( $O$ człowiekù, co miôt strach smiercë). Użyty w kaszubskim zwrocie przysłówek sztram oznacza 'silnie, mocno' (Sychta 1965-1976, V: 301). Połączenia wyrazowego włosë stôwatë mù sztram nie odnajdujemy w słownikach kaszubszczyzny, mamy tu zatem do czynienia z przekładem syntagmatycznym, którego uzasadnieniem najpewniej było dążenie do tego, aby tłumaczona baśń była jak najbliższa tekstowi w języku wyjściowym. Trzeba jednak zauważyć, że w kaszubszczyźnie funkcjonują związki frazeologiczne, których można użyć w odniesieniu do kogoś, kogo obejmuje strach, np.: miec fùl bùksë strachù (Sychta 1965-1976, V: 170), miec strach jak wilk ògnia (Gołąbek 2012-2013, I: 51), tymczasem tłumacz zdecydował się żadnego z nich nie uwzględnić.

Dosłowny przekład struktury frazeologicznej odnajdujemy również w kaszubskiej wersji baśni Jana Drzeżdżona pt. Człowiek śmiechu. W polskim pierwowzorze tego utworu odnotowany został związek frazeologiczny być w czyichś rękach oznaczający 'być od kogoś całkowicie zależnym' (Dubisz, Sobol 2005: 438-439; Bąba, Liberek 2003: 676). Zwrot ten został zarejestrowany w polskojęzycznym oryginale dwukrotnie w następującym kontekście: „Zdał sobie sprawę, że jego los jest w jej rękach. Ilekroć znajdował się między ludźmi i oni przechodzili obok niego, nie zwracając nań uwagi, zawsze myślał o niej, że jest w jej rękach”. W przywołanym fragmencie mowa jest o tym, że tytułowy bohater Człowiek śmiechu uświadamia sobie, że jego życie i jego los jest zależny od młodej dziewczyny, która jako jedyna wśród wszystkich napotkanych ludzi nie śmiała się z jego niekształtnej twarzy. Pewnym rozwiązaniem byłoby opisowe przetłumaczenie przywołanej wyżej struktury frazeologicznej, tymczasem tłumacz zdecydował się na dosłowną jej translację w obu wyżej zacytowanych zdaniach, które w wersji kaszubskiej, zatytułowanej Człowiek smiéchù, brzmią następująco: „Zmerkôł., że jegò żëcé je w ji rãkach. Czej béł midzë lëdzama ë òni szlë wedle, nijak na niegò nie zdrzącë, wiedno mëslôł ò tim, że je w ji rãkach". Także w tym przykładzie translację z użyciem kalk językowych z polszczyzny należy uznać za nieadekwatną. Trzeba nadmienić, że w kaszubszczyźnie można wskazać związek frazeologiczny, który odzwierciedlałby takie samo znaczenie, jak to użyte w pierwowzorze, mianowicie jest to zwrot miec nad kims górã (Gołąbek 2012-2013, III: 23).

Dość częstą strategią Romana Drzeżdżona podczas przekładu baśni było eliminowanie pojawiających się w polskiej wersji utworów związków frazeologicznych i zastępowanie ich właściwymi kaszubszczyźnie wyrazami lub połączeniami wyrazowymi niemającymi 
charakteru frazeologizmów. W dalszej części pierwowzoru przywołanej wyżej baśni pt. Człowiek śmiechu została odnotowana struktura frazeologiczna brać się z kimś za bary, oznaczająca 'zmobilizować się do pokonania czegoś sprawiającego trudność, zmierzyć się z trudnościami, podejmować jakieś wyzwanie, próbować przeciwstawić się komuś, chcieć coś opanować' (Dubisz, Sobol 2005: 13; Bąba, Liberek 2003: 29; Skorupka 1977, I: 98). W baśni Jana Drzeżdżona mowa jest o tym, że bohater „weźmie się za bary ze śmiercią”, czyli będzie próbował nie dopuścić jej do siebie. Kaszubski tłumacz powyższy frazeologizm przetłumaczył za pomocą czasownika chwacëc sã k który w kaszubszczyźnie oprócz znaczenia 'chwycić się' jest używany jako odpowiednik polskiego 'bić się'. Romanowi Drzeżdżonowi najpewniej chodziło o to drugie znaczenie formy chwacëc sã , jednakże nie można przyjąć, że jest to przekład właściwy. Nie tylko mamy tu do czynienia z brakiem odzwierciedlenia obrazowości i ekspresywności zawartej w związku frazeologicznym, ale też z przesunięciem znaczeniowym. Tymczasem w kaszubszczyźnie istnieje zwrot mający taką samą wymowę jak frazeologizm użyty w pierwowzorze: jic w bartczi (Ramułt 2003: 27).

Przekład związku frazeologicznego, którego ekwiwalentem w języku docelowym jest zwrot niefunkcjonujący w kaszubszczyźnie jako frazeologizm, został odnotowany w translacji baśni pt. Stary młyn. W utworze tym pojawił się związek frazeologiczny pozostawić komuś wolna rękę, oznaczający 'pozwolić komuś działać, samodzielnie decydować o czymś' (Dubisz, Sobol 2005: 439; Bąba, Liberek 2003: 677). Struktura ta wystąpiła w następującym kontekście: „krawiec zawinił, bo mógł pozostawić synom wolną rękę, może dokonaliby tego, co zamierzali, a tak nie mógł pokonać jego starości”. W kaszubskim przekładzie zatytułowanym Stôri mtin tłumacz wyeliminował konstrukcję frazeologiczną i zastąpił go zwrotem dac kòmùs wòla 'dać komuś wolny wybór', niemającym charakteru frazeologizmu. Tłumaczenie powyżej przywołanego fragmentu na język kaszubski ma następującą postać: „,winã miôł krôwc, bò mógł dac sënóm wòlą, mòże bë zrobilë to, co chcelë, a tak ni mòglë dobëc nad jegò staroscą".

Charakter idiomu ma też użyty w pierwowzorze baśni Deszczowy człowiek związek zalewała go fala wielkiego przygnębienia. Tego połączenia wyrazowego możemy użyć, gdy chcemy powiedzieć, że ktoś jest bardzo smutny, przygnębiony, ma zły nastrój. Motyw zalewającej fali ma wskazywać na intensywność negatywnych uczuć. Bohater utworu był bardzo przygnębiony, ponieważ miał świadomość, że nie jest człowiekiem, tylko potworem. Romanowi Drzeżdżonowi nie udało się znaleźć ekwiwalentnego frazeologizmu w kaszubszczyźnie i przełożył on go jako béł smùtny (Deszczowi człowiek). W tłumaczeniu utracone zostało pojawiające się w oryginale obrazowanie i ekspresywność, a przekład nie może być uznany za adekwatny, ponieważ nie została w nim odzwierciedlona intensywność uczucia opisanego w oryginalnym polskim tekście baśni.

Również w tej samej baśni pt. Deszczowy człowiek został odnotowany frazeologizm pędzić na złamanie karku, oznaczający 'pędzić bardzo szybko, co tchu, w wielkim pośpiechu, na oślep, narażając się na niebezpieczeństwo, nie zważając na przeszkody’ (Dubisz, Sobol 2005: 223-224; Bąba, Liberek 2003: 266; Skorupka 1977, I: 318). W utworze mowa jest o tym, że ludzie „uciekali do swoich domów i zamykali drzwi, pędzili na złamanie karku i kryli się, gdzie kto mógł”. Kaszubski tłumacz nie znalazł w kaszubszczyźnie adekwatnego odpowiednika użytego w pierwowzorze związku frazeologicznego, ale starał się odzwierciedlić jego sens opisowo z wykorzystaniem metafory niemającej charakteru fraze- 
ologizmu. Roman Drzeżdżon przełożył omawianą tu strukturę frazeologiczną następująco: „nëkële tak flot, jaż szpérë so łómiale”, co w dosłownym tłumaczeniu na polszczyznę oznacza 'pędzili tak szybko, że aż nogi sobie łamali'. Opisowa wykładnia nie jest najlepszym sposobem translacji, jednak jest to metoda akceptowalna, gdy nie istnieje w języku docelowym pełny ekwiwalent frazeologizmu. Tymczasem w kaszubszczyźnie można znaleźć związki frazeologiczne, które są odpowiednikami zwrotu użytego w pierwowzorze, tj. nëkac na zabicé, nëkac jak dzëczi (Gołąbek 2012-2013, III: 59)

Z kolei w baśni pt. Gotujace się buty pojawił się zwrot frazeologiczny mówić od rzeczy, czyli 'mówić coś, w co trudno uwierzyć, mówić bez sensu, wygadywać głupstwa, niedorzeczne słowa, wygadywać nonsensy, zmyślać' (Dubisz, Sobol 2005: 460). W utworze mowa jest o tym, że buty, a za nimi chłopiec, doszły do pewnego królestwa i ludność tej krainy uczyniła tego młodego człowieka, który podążał za butami, swoim królem; jednego dnia buty zaczęły się gotować, a kroczący za nimi chłopiec całkowicie oszalał; wtedy ludność królestwa „straciła pamięć i zaczęła mówić od rzeczy”. Romanowi Drzeżdżonowi nie udało się znaleźć ekwiwalentnego związku frazeologicznego i zdecydował się przełożyć do za pomocą parafrazy; w kaszubskiej translacji zatytułowanej Warzacé sã bótë czytamy: „Æëdze z królestwa stracëlë pamiãc ë zaczãlë plestac czësto głupie”. Warto odnotować, że w kaszubszczyźnie istnieje frazeologizm trzepòtac trzë pò trzë (Gołąbek 2012-2013, II: 224), mający takie samo znaczenie jak zwrot użyty w tekście wyjściowym.

Wprowadzanie przez Romana Drzeżdżona w przekładzie struktur frazeologicznych w miejscach, w których w pierwowzorze nie zostały użyte frazeologizmy, można uznać za przejawy strategii kompensacji. W różnych utworach znajdujących się w zbiorze Baśnie. Brawãdë kilkukrotnie thumacz zastosował kaszubski zwrot frazeologiczny bëc òd se, który jest wieloznaczny i może być użyty w kilku znaczeniach: 'być oszołomionym, być zmieszanym, zdezorientowanym, ogłupiałym, zdenerwowanym', 'stracić panowanie nad sobą', 'stracić zmysły', 'być nieprzytomnym' (Sychta 1965-1976, V: 24). W baśni Jana Drzeżdżona pt. Człowiek śmiechu mowa jest o tym, że bohaterka była nieprzytomna; autor przekładu w miejsce przymiotnika nieprzytomna wprowadził frazeologizm bëc òd se; w tekście tłumaczenia czytamy: „Dzéwczã leżało czësto òd se”. Z kolei w utworze Diana pojawił się motyw zmieszania, czyli 'zakłopotania, znajdowania się w krępującej sytuacji'. W polskim pierwowzorze odnotowany został fragment: „Człowiek zadrżał, a Diana zauważyła od razu jego zmieszanie". W kaszubszczyźnie nie ma jednego wyrazu, który byłby dokładnym znaczeniowym ekwiwalentem wyrazu zmieszanie i Roman Drzeżdżon wprowadził w tym miejscu związek frazeologiczny bëc òd se; powyżej zacytowane zdanie zostało przełożone następująco: „Człowiek zadrëżôł, a Diana zarô zmerka, że je òn òd se” (Diana). W kolejnym fragmencie tej samej baśni tłumacz użył frazeologizmu bëc òd se jako odpowiednika przymiotnika oszołomiony. W polskim pierwowzorze czytamy: „Oszołomiony zapomniał się rozejrzeć, czy naprawdę nie ma już żadnego niebezpieczeństwa”; fragment ten otrzymał następujące thumaczenie: „Béł czësto òd se, a zabéł sã rozezdrzec, czë pò prôwdze je bezpieczno". Ostatnim utworem Jana Drzeżdżona, w którym kaszubski tłumacz wprowadził związek frazeologiczny bëc òd se, jest baśń pt. O człowieku, który bat się śmierci. W dziele tym mowa jest o tym, że bohater „czuł się odurzony ciepłem”. Zwrot ten w wersji kaszubskojęzycznej ma następującą postać: „Bez no cepło, co òd ni czuł, béł czësto òd se”.

Natomiast posłużenie się przez Romana Drzeżdżona w przekładzie baśni Adam i Ewa kaszubskim związkiem frazeologicznym nëkac z bùksama użytym w miejscu polskiego 
czasownika sikać należy rozpatrywać jako próbę eufemizacji. W oryginalnym polskim tekście omawiane słowo pojawiło się w następującym kontekście: „Mylicie się - rzekł szewc - diabeł nie powstał z żadnej jabłoni, lecz ze strachu niebian, przecież oni co chwilę sikają, tak się boją wszystkiego”. Fragment ten otrzymał następujące tłumaczenie: „Wa jesta pòmilony - rzekł szewc - diôbeł nie pòwstôł z niżódny jabłónczi, le ze strachù niebianów, doch òni co sztót nëkają z bùksama, tak mają strach wszëtczégò" (Adóm i Éwa). Gdyby autor translacji zdecydował się na dokładny przekład i chciał uniknąć użycia związku frazeologicznego, to musiałby posłużyć się kaszubskim wyrazem szczac, który ma negatywne konotacje. Eufemizm nëkac z bùksama zdaje się być bardziej pożądany ze względów obyczajowych.

Jak pokazuje przeprowadzona analiza, tłumacz zbioru Jana Drzeżdżona pt. Baśnie. Brawãdë w różny sposób dokonywał translacji struktur frazeologicznych na język kaszubski. Kilkukrotnie Roman Drzeżdżon zdecydował się na dosłowny przekład i w żadnym wypadku nie był to udany wybór translatorski. Kalki językowe z polszczyzny należy uznać za taki komponent strategii egzotyzacji, który wiąże się z przekroczeniem kompetencji autora thumaczenia (Makurat 2017a: 282, Makurat 2017c: 103). Przekłady na kaszubszczyznę powinny służyć wzmocnieniu statusu języka regionalnego wśród innych języków (Kuik-Kalinowska 2012: 46), tymczasem przykłady syntagmatycznych tłumaczeń pokazują niedostatki języka kaszubskiego i podważają jego niezależność.

Dokonywanie przez tłumacza dosłownych przekładów wynika najpewniej z założenia, że czytelnik tekstów kaszubskojęzycznych jest osobą bilingwalną, znającą oprócz kaszubszczyzny język polski, i w związku ze swoimi kompetencjami odnoszącymi się do polszczyzny najpewniej będzie w stanie rozpoznać oraz zrozumie skaszubione polskojęzyczne struktury frazeologiczne. Motywem, który skłonił Romana Drzeżdżona do wprowadzania kalk polskich frazeologizmów, może być też podobieństwo polszczyzny i kaszubszczyzny wynikające z przynależności do jednej rodziny językowej (zachodniosłowiańskiej) oraz wielowiekowych kontaktów tych języków i obustronnych interferencji. Trzeba jednak zaakcentować, że syntagmatyczny przekład polskojęzycznych jednostek frazeologicznych może wskazywać na to, że kaszubszczyzna nie jest tu traktowana jako odrębny, zdolny do samodzielnego funkcjonowania język, ale jako etnolekt wciąż zależny od polszczyzny (Makurat 2017a: 283-285, Makurat 2017b: 237-248, Makurat 2017c: 103).

Standardowy język kaszubski jest stosunkowo młody, w związku z czym nie wykształcił on całej leksyki potrzebnej do nazwania różnych elementów świata. Autorzy kaszubskich tekstów wobec braku odpowiedniego słownictwa nieraz przejmują odpowiednie wyrazy z polszczyzny (Makurat 2015: 98-99). Taka tendencja widoczna jest też w opracowaniach leksykograficznych Eugeniusza Gołąbka takich, jak: Kaszëbsczi słowôrz normatiwny (Gòłąbk 2002) oraz Słownik polsko-kaszubski (Gołąbek 2012-2013). O ile przejmowanie leksyki z języka blisko spokrewnionego może być nieraz umotywowane, to przyswajanie z języka obcego frazeologizmów - połączeń wyrazowych, które z definicji są utrwalone w rodzimym języku i jego tradycji - nie ma już takiego uzasadnienia (Makurat 2017a: 285).

W kaszubskiej wersji baśni Jana Drzeżdżona można również znaleźć liczne opisowe wykładnie związków frazeologicznych; parafrazy są zasadniczo udane i odzwierciedlają właściwy sens frazeologizmów. Zastrzeżenia może budzić jednak fakt, że tłumacz nie znalazł w zasobach kaszubszczyzny ani jednej w pełni ekwiwalentnej struktury frazeologicz- 
nej, co nie wynikało z niedostatecznego zasobu frazeologizmów w kaszubszczyźnie. Pewną próbą wyrównania strat było posłużenie się przez Romana Drzeżdżona strategią kompensacji i wprowadzenie struktur frazeologicznych w miejscu wyrazów lub połączeń wyrazowych, które w pierwowzorze nie miały charakteru frazeologizmów.

\section{Bibliografia}

Bąba Stanisław, Liberek Jarosław, 2003, Stownik frazeologiczny współczesnej polszczyzny, Warszawa.

Dąmbska-Prokop Urszula (red.), 2000, Mała encyklopedia przekładoznawstwa, Częstochowa.

Drzeżdżon Jan, 2012, Baśnie. Brawãdë, tłum. Roman Drzeżdżon, Gdańsk.

Dubisz Stanisław, Sobol Elżbieta (red.), 2005, Wielki słownik frazeologiczny PWN z przysłowiami, Warszawa.

Gołąbek Eugeniusz, 2012-2013, Wielki słownik polsko-kaszubski, t. I-III, Gdańsk.

Gołąbek Eugeniusz, Stownik polsko-kaszubski, t. I, II, http://skarbnicakaszubska.pl/slownik-polskokaszubski-start/ [6.11.2016].

Gòłąbk Eùgeniusz, 2002, Kaszëbsczi stowôrz normatiwny, Kartuzy.

Hejwowski Krzysztof, 2007, Kognitywno-komunikacyjna teoria przekładu, Warszawa.

Kalinowski Daniel, 2007, Drzeżdżon intertekstualny. Przypadek „Karamoro”, w: Renata Mistarz (red.), Twarze Drzė̇dżona, Gdańsk, s. 49-67.

Kalinowski Daniel, 2012, Współczesna literatura powszechna w tlumaczeniu na język kaszubski, w: Radosław Kamiński (red.), Tłumaczenia na język kaszubski. Osiagnięcia, metody, cele (Materiaty pokonferencyjne), Wejherowo, s. 29-38.

Kochański Witold, Klebanowska Barbara, Markowski Andrzej, 1989, O dobrej i złej polszczyźnie, Warszawa.

Koller Werner, 2007, Probleme der Übersetzung von Phrasemen, w: Harald Burger, Dmitrij Dobrovol'skij, Peter Kühn, Neal Norrick (red.), Phraseologie. Ein internationales Handbuch der zeitgenössischen, Berlin - New York, s. 605-613.

Krysztofiak Maria, 1996, Przekład literacki we współczesnej translatoryce, Poznań.

Kuik-Kalinowska Adela, 2012, Klasyka literatury polskiej po kaszubsku. Rekonesans badawczy, w: Radosław Kamiński (red.), Tłumaczenia na język kaszubski. Osiagnięcia, metody, cele (Materiaty pokonferencyjne), Wejherowo, s. 39-46.

Makurat Hanna, 2015, Sposób istnienia kaszubskojęzycznego tekstu. Wzajemne relacje między systemem językowym kaszubszczyzny a wypowiedzia zbudowana w tym języku, w: Małgorzata Klinkosz, Aneta Lica, Zenon Lica (red.), Językowy, literacki i kulturowy obraz Pomorza, t. 2, Gdańsk, s. $95-104$.

Makurat Hanna, 2017a, Frazeologizmy w przekładzie na język kaszubski książki Balbina z IV B Danuty Stanulewicz. Krytyka przyjętej przez thumaczkę strategii translatorskiej, „Zeszyty Łużyckie", t. 51, s. 273-288.

Makurat Hanna, 2017b, W jakim zakresie tlumacz tekstów literackich z języka polskiego na kaszubszczyznę jest pośrednikiem między kulturami?, „Rocznik Przekładoznawczy. Studia nad teorią, praktyką i dydaktyką przekładu", nr 12, s. 237-248.

Makurat Hanna, 2017c, Frazeologizmy i przysłowia w przekładzie bajek Iwana Kryłowa z języka rosyjskiego na kaszubszczyznę, „Prace Językoznawcze”, XIX/4, s. 93-105.

Polański Kazimierz (red.), 2003, Encyklopedia językoznawstwa ogólnego, Wrocław.

Ramułt Stefan, 2003, Stownik języka pomorskiego, czyli kaszubskiego, scalił i znormalizował Jerzy Treder, według wydań Akademii Umiejętności z roku 1893 i Polskiej Akademii Umiejętności z roku 1993, Gdańsk. 
Skorupka Stanisław, 1977, Stownik frazeologiczny języka polskiego, t. 1-2, Warszawa.

Stanulewicz Danuta, 2015, Balbina z IV B, tłum. Bożena Ugowska, Gduńsk.

Sychta Bernard, 1965-1976, Stownik gwar kaszubskich na tle kultury ludowej, t. I-VII, Wrocław.

Treder Jerzy (red.), 2006, Język kaszubski. Poradnik encyklopedyczny, Gdańsk.

Wojtasiewicz Olgiert, 1992, Wstęp do teorii thumaczenia, Warszawa.

Мокиенко Валерий Михайлович, 2014, Переводимое и непереводимое во фразеологии, w: Wojciech Chlebda (red.), Frazeologia a przekład, Opole, s. 11-24.

\title{
HANNA MAKURAT
}

\section{Phrasemes in translation into Kashubian in fairy tales by Jan Drzeżdżon}

\begin{abstract}
Summary
The article discusses the methods used to translate phrasemes in the Kashubian version of the book Baśnie. Brawãdë by Jan Drzeżdżon. The translator, Roman Drzeżdżon, was unable to find any equivalent phrasemes in the target language. He translated them literally or described their meaning. Moreover, he also used the compensation strategy and introduced phrasemes in places where they were absent in the original.
\end{abstract}

Keywords: translation, Kashubian language, phrasemes, fairy tales 